\title{
HUBUNGAN MOBILISASI DINI POST SECTIO CAESAREA DENGAN PENYEMBUHAN LUKA OPERASI DI RSU AVICENNA KECAMATAN KOTA JUANG KABUPATEN BIREUEN
}

\section{The Relationship Of Early Post Sectio Caesarea Mobilization With Surgical Wound Healing In The Nursing Room Of Avicenna Hospital Juang City District Bireuen District In 2019}

\author{
Ferinawati $^{* 1}$, Rita Hartati ${ }^{2}$ \\ 1. Dosen Akbid Munawarah, Jl. Sultan Iskandar Muda No. 18 Kota Juang, Bireuen 24251, Indonesia \\ 2. Mahasiswa Akbid Munawarah, Jl. Sultan Iskandar Muda No. 18 Kota Juang, Bireuen 24251, Indonesia \\ *Korespondensi Penulis : ferinabireuen88@gmail.com*1, ritahartati109gmail.com²
}

\begin{abstract}
Abstrak
Menurut World Health Organization (WHO), rata-rata Sectio Caesarea 5-15\% per 1000 kelahiran di dunia, angka kejadian dirumah sakit pemerintah rata-rata $11 \%$, sementara dirumah sakit swasta bisa lebih dari 30\%. Angka kejadian Sectio caesarea di Indonesia menurut data survey nasional tahun 2007 adalah 927.000 dari 4.030 .000 persalinan (Kemenkes RI, 2013). Penelitian ini dilakukan untuk mengetahui Hubungan Mobilisasi Dini Post Sectio Caesarea dengan Penyembuhan Luka Operasi di Ruang Rawat RSU Avicenna Kecamatan Kota Juang Kabupaten Bireuen Tahun 2019.

Desain penelitian yang digunakan adalah penelitian analitik dengan pendekatan cross sectional. Pengambilan sampel dilakukan secara accidental sampling dengan sampel berjumlah 32 responden. Pengumpulan data menggunakan kuesioner dan lembar observasi. penelitian ini dilakukan di RSU Avicenna Kecamatan Kota Juang Kabupaten Bireuen pada bulan Mei s/d Juni 2019.

Dari hasil penelitian menunjukkan bahwa sebagian besar responden yang melakukan mobilisasi dini post Sectio Caesarea yaitu 21 responden $(65,6 \%)$, dan sebagian penyembuhan luka terjadi secara cepat yaitu 22 responden $(68,8 \%)$. Berdasarkan hasil uji silang ibu dengan penyembuhan luka operasi dengan kategori lambat adalah pasien yang tidak melakukan mobilisasi dengan baik yaitu sebanyak 8 responden (25\%). Dari hasil uji Chi-square didapatkan nilai $\rho(0.001)<\quad(0.05)$.

Berdasarkan hasil uji Chi-square didapatkan nilai $\rho(0.001)<(0.05)$, sehingga ada hubungan antara mobilisasi dini post Sectio Caesarea dengan penyembuhan luka operasi.
\end{abstract}

\section{Kata Kunci : Mobilisasi Dini Post Sectio Caesarea , Penyembuhan Luka Operasi}

\begin{abstract}
According to the World Health Organization (WHO), the average Caesarean section is 5$15 \%$ per 1000 births in the world, the incidence in government hospitals is an average of $11 \%$, while in private hospitals it can be more than 30\%. The incidence of Sectio caesarea in Indonesia according to the national survey data in 2007 was 927,000 from 4,030,000 deliveries (Ministry of Health, 2013). This study aims to determine the relationship of Early
\end{abstract}


Journal of Healthcare Technology and Medicine Vol. 5 No. 2 Oktober 2019

Universitas Ubudiyah Indonesia

e-ISSN : 2615-109X

Post Sectio Caesarea Mobilization with Surgical Wound Healing in the Nursing Room of Avicenna Hospital, Juang City District, Bireuen District in 2019.

This type of research is analytical research with a cross sectional approach. The sampling was done by accidental sampling with a sample of 32 respondents. The data collection using questionnaires and observation sheets. this research was conducted at Avicenna Bireuen general Hospital on 24-31 may 2019.

Based on the results showed that the majority of respondents who did early Sectio Caesarea post mobilization were 21 respondents (65.6\%), and partially healing wounds occurred quickly, namely 22 respondents (68.8\%). Based on the results of cross-examination of mothers with healing surgical wounds in the slow category are patients who did not mobilize well as many as 8 respondents (25\%). From the Chi-square test results, the value of $\rho(0.001)$ $<(0.05)$ is obtained.

Based on the results of the Chi-square test obtained $\rho(0.001)<(0.05)$, so there is a relationship between early mobilization of post sectio caesarea with surgical wound healing.

Keywords : Early Post Sectio Caesarean Mobilization, Surgical Wound Healing

\section{PENDAHULUAN}

Menurut World Health Organization (WHO), rata-rata SC 5-15\% per 1000 kelahiran didunia, angka kejadian dirumah sakit pemerintah rata-rata $11 \%$, sementara dirumah sakit swasta bisa lebih dari 30\%. Permintaan Sectio Caesarea disejumlah negara berkembang melonjak pesat setiap tahunnya (Judhita, 2009 dalam Sriyanti, 2016). Selain itu menurut WHO prevalensi SC meningkat $46 \%$ di Cina dan 25\% di Asia, Eropa, dan Amerika Latin (Sujata, 2014). Hal ini didukung oleh Corso, et al (2017) yang menyatakan bahwa Sectio Caesarea menjadi salah satu kejadian pravelensi yang meningkat didunia. Jumlah persalinan Sectio Caesarea di Indonesia mencapai sekitar 30-80\% dari total persalinan. Angka kejadian Sectio Caesarea di Indonesia menurut data survey nasional tahun 2007 adalah 927.000 dari 4.030.000 persalinan (Kemenkes RI, 2013).

Komplikasi masa kehamilan, persalinan dan nifas merupakan masalah kesehatan yang penting, jika tidak ditanggulangi bisa menyebabkan kematian ibu yang tinggi. Tragedi yang mencemaskan dalam proses reproduksi salah satunya kematian yang terjadi pada ibu. Keberadaan seorang ibu adalah tonggak untuk keluarga sejahtera. Untuk itu Indonesia 
Journal of Healthcare Technology and Medicine Vol. 5 No. 2 Oktober 2019

Universitas Ubudiyah Indonesia

e-ISSN : 2615-109X

mempunyai target pencapaian kesehatan melalui SDKI 2012 AKI meengalami kenaikan yaitu menjadi 359/100.000 kelahiran hidup. Perlu upaya keras apabila melihat target nasional menurut Sustinable Development Goals (SDGS) yaitu menurunkan AKI menjadi 306/100.000 kelahiran hidup pada tahun 2019 (Kemenkes RI, 2015)

Persalinan adalah serangkaian kejadian yang berakhir dengan pengeluaran bayi yang cukup bulan atau hampir cukup bulan, disusul dengan pengeluaran plasenta dan selaput janin dari tubuh ibu melalui jalan lahir atau melalui jalan lain, berlangsung dengan bantuan atau tanpa bantuan (kekuatan ibu sendiri) (Tritestuti, 2018).

Salah satu cara di dalam persalinan adalah dengan Sectio Caesarea. persalinan dengan Sectio Caesarea memiliki resiko tinggi karena dilakukan pembedahan dengan membuka dinding perut dan dinding uterus atau insisitransabdominal uterus, sehingga pasien akan merasakan rasa nyeri. Rasa nyeri merupakan stressor yang dapat menimbulkan stress dan ketegangan dimana individu dapat berespon secara biologis dan perilaku yang menimbulkan respon fisik dan psikis ( Rusca P, 2012).

Sectio Caesarea adalah suatu pembedahan guna melahirkan anak lewat insisi pada dinding abdomen dan uterus. Tindakan SC disebabkan oleh 2 faktor indikasi yaitu faktor ibu dan faktor janin. Faktor ibu antara lain panggul sempit dan distosia mekanis, pembedahan sebelumnya pada uterus, riwayat SC, perdarahan dan toxemia gravidarum. Faktor janin antara lain gawat janin, cacat atau kematian janin sebelumnya, insufesiensi plasenta, malpresentasi, janin besar, inkompatibilitas rhesus, postmortem caecarean dan infeksi virus herpes (Forte, 2010).

Luka post Sectio Caesarea merupakan luka yang membekas dan disebabkan oleh bedah Caesar ketika wanita tidak dapat melahirkan secara normal. Proses ini ditempuh karena adanya suatu hambatan untuk proses persalinan normal diantaranya seperti lemahnya tenaga 
Journal of Healthcare Technology and Medicine Vol. 5 No. 2 Oktober 2019

Universitas Ubudiyah Indonesia

e-ISSN : 2615-109X

sang ibu untuk melahirkan, detak jantung bayi lemah, ukuran bayi terlalu besar dan lainnya (Puspitasari, 2011)

Dengan adanya luka bekas operasi Sectio Caesarea menimbulkan nyeri pada pasien sehingga pasien cenderung untuk berbaring saja, untuk mempertahankan seluruh tubuh kaku dan tidak mengindahkan daerah pembedahan sehingga menimbulkan kaku persendian, postur yang buruk, kontraktur otot, nyeri tekan apabila tidak melakukan mobilisasi dini (Christina)

Mobilisasi dini yang dilakukan tergantung pada ada tidaknya komplikasi persalinan dan nifas. Pada ibu post Sectio Caesarea diperbolehkan bangun dari tempat tidur paling lama 24-48 jam setelah melahirkan. Untuk itu, anjurkan ibu agar memulai mobilisasi dini dengan miring kiri atau kanan, duduk kemudian berjalan (Astutik, 2015)

Mobilisasi penting dilakukan untuk mempercepat kesembuhan ibu sehingga dapat melakukan kembali aktifitas sehari-hari secara normal. Keterlambatan mobilisasi ini akan menjadikan kondisi ibu semakin memburuk dan menjadikan pemulihan pasca Sectio Caesarea menjadi terlambat (Marfuah, 2015).

Beberapa hasil penelitian yang dilakukan sebelumnya oleh Rimayanti Simangunsong (2018) tentang hubungan mobilisasi dini dengan penyembuhan luka post Sectio Caesarea dengan jumlah pasien sampel 30 orang ibu post operasi Caesar didapatkan hasil 96,0\% yang melakukan mobilisasi dini proses penyembuhan lukanya cepat dan 4,0\% yang tidak melakukan mobilisasi dini proses penyembuhan lukanya lambat.

Hasil Riskesdas tahun 2013 menunjukkan kelahiran dengan metode operasi Caesar sebesar 9,8\% dari total 49,603 kelahiran sepanjang tahun 2010 sampai 2013. Sedangkan menurut Profil Kesehatan Indonesia (2014) jumlah ibu dengan persalinan Sectio Caesarea sebanyak $18,5 \%$. 
Journal of Healthcare Technology and Medicine Vol. 5 No. 2 Oktober 2019

Universitas Ubudiyah Indonesia

e-ISSN : 2615-109X

Menurut data Survey Nasional Indonesia pada tahun 2007 angka persalinan 921.000 dari 4.039.000 persalinan atau sekitar 22,8\%. Kasus sectio caesarea adalah 40-80 tiap 100.000 kelahiran hidup. Sedangkan menurut profil kesehatan Aceh tahun 2013 jumlah persalinan dengan sectio caesarea yaitu sebanyak 52,7\%.

Berdasarkan survey awal yang dilakukan di RSU Avicenna Bireuen, diperoleh data pada tahun 2019 pasien post Sectio Caesarea yang dirawat di RSU Avicenna Bireuen pada bulan Januari sampai April sebanyak 388 ibu post Sectio Caesarea. Hasil wawancara dengan salah satu bidan didapatkan bahwa bidan selalu menganjurkan semua pasien post operasi Sectio Caesarea untuk melakukan mobilisasi dini. Namun, ada beberapa pasien yang tidak mengikuti anjuran dan mengakibatkan kepulangan yang lebih lama dari pasien lain karena mengalami infeksi pada luka. Hal ini selaras dengan kejadian infeksi pada bulan Januari April yaitu sebanyak 15 kejadian. Hasil observasi juga menunjukkan 3 dari 7 ibu post operasi Sectio Caesarea tidak melakukan mobilisasi dini dengan alasan takut karena masih merasa nyeri pada luka insisi.

Berdasarkan latar belakang tersebut, maka peneliti tertarik untuk meneliti tentang "Hubungan Mobilisasi Dini Post Sectio Caesarea dengan Penyembuhan Luka Operasi di Ruang Rawat RSU Avicenna Bireuen Tahun 2019”

Tujuan penelitian ini Untuk mengetahui hubungan mobilisasi dini post Sectio Caesarea (SC) dengan penyembuhan luka operasi di Ruang Rawat RSU Avicenna Bireuen .

\section{METODE PENELITIAN}

Jenis penelitian ini adalah penelitian analitik. Desain penelitian ini menggunakan desain pendekatan Cross Sectional. Lokasi penelitian di lakukan di RSU Avicenna Kecamatan Kota Juang Kabupaten Bireuen tahun 2019. Waktu penelitian dimulai dari bulan Mei sampai dengan Juni 2019. Populasi dalam penelitian ini adalah seluruh ibu post partum dengan tindakan Sectio Caesarea di RSU Avicenna Bireuen. Tehnik pengambilan sampel 
Journal of Healthcare Technology and Medicine Vol. 5 No. 2 Oktober 2019

Universitas Ubudiyah Indonesia

e-ISSN : 2615-109X

menggunakan tehnik accidental sampling yaitu berjumlah 32 responden. Data dianalisis secara univariat dan bivariat dengan uji chi-square.

\section{HASIL PENELITIAN}

Analisis Univariat digunakan untuk mengetahui distribusi frekuensi tentang kecemasan, pengetahuan, perubahan fisik dan dukungan keluarga.

Tabel 1. Distribusi Frekuensi Mobilisasi Dini Post Sectio Caesarea di Ruang Rawat RSU Avicenna Bireuen Tahun 2019.

\begin{tabular}{ccc}
\hline Analisis Univariat & \multicolumn{2}{c}{ Jumlah } \\
\cline { 2 - 3 } & $\mathbf{f}$ & $\mathbf{( \% )}$ \\
\hline Mobilisasi Dini & 21 & 65,6 \\
Baik & 11 & 34,4 \\
Kurang & 22 & 68,8 \\
Penyembuhan Luka & 10 & 531,2 \\
Cepat & $\mathbf{3 2}$ & $\mathbf{1 0 0}$ \\
\hline Lambat & &
\end{tabular}

Berdasarkan tabel diatas, dapat dilihat mayoritas ibu post Sectio Caesarea melakukan mobilisasi dini dengan kategori baik yaitu sebanyak 21 responden (65,5\%). Mayoritas responden mengalami penyembuhan luka dengan kategori cepat yaitu sebanyak 22 responden $(68,8 \%)$

Analisis Bivariat digunakan untuk mengetahui hubungan antara variabel independen terhadap variabel dependen dengan menggunakan chi-square pada tingkat kemaknaan 95\% atau nilai $(\alpha=0,05)$. Bila menunjukan nilai $\mathrm{p} \leq 0,05$ artinya ada hubungan bermakna atau signifikan. 
Journal of Healthcare Technology and Medicine Vol. 5 No. 2 Oktober 2019

Universitas Ubudiyah Indonesia

e-ISSN : 2615-109X

Tabel 2. Uji Silang Mobilisasi Dini Post Sectio Caesarea Dengan Penyembuhan Luka Operasi di Ruang Rawat RSU Avicenna Bireuen Tahun 2019.

\begin{tabular}{|c|c|c|c|c|c|c|c|}
\hline \multirow{3}{*}{ Analisis Bivariat } & \multicolumn{6}{|c|}{ Penyembuhan Luka Operasi } & \multirow{3}{*}{ P-Value } \\
\hline & \multicolumn{2}{|c|}{ Cepat } & \multicolumn{2}{|c|}{ Lambat } & \multicolumn{2}{|c|}{$\sum$} & \\
\hline & Jlh & $\%$ & Jlh & $\%$ & Jlh & $\%$ & \\
\hline \multicolumn{8}{|l|}{$\begin{array}{l}\text { Mobilisasi Dini Post } \\
\text { Sectio Caesarea }\end{array}$} \\
\hline Baik & 19 & 59,4 & 2 & 6,2 & 21 & 65,6 & \multirow{2}{*}{0,001} \\
\hline Kurang & 3 & 9,4 & 8 & 25 & 11 & 34,4 & \\
\hline Jumlah & 22 & 68,8 & 10 & 31,2 & 32 & 100 & 100 \\
\hline
\end{tabular}

Berdasarkan uji silang diatas dapat dilihat bahwa dari 32 responden, terdapat 21 responden $(65,6)$ yang dapat melakukan mobilisasi dini dengan kategori baik, dimana mayoritas atau 19 responden $(59,4)$ mengalami penyembuhan luka dengan cepat dan minoritas atau 2 responden $(6,2)$ yang mengalami penyembuhan luka secara lambat. Sedangkan $11(34,4 \%)$ responden yang melakukan mobilisasi dini dengan kategori kurang dengan mayoritas penyembuhan luka secara lambat yaitu 8 responden $(25 \%)$ dan minoritas penyembuhan secara cepat yaitu 3 responden $(9,4 \%)$.

Hasil uji statistik Chi-square antara mobilisasi dini post Sectio Caesarea dengan penyembuhan luka operasi diperoleh nilai Exact Sig. 2-sided $(0.001)<(0,05)$. Jadi Ha diterima H0 ditolak. Maka ada hubungan antara mobilisasi dini post Sectio Caesarea dengan penyembuhan luka operasi di RSU Avicenna bireuen tahun 2019.

\section{PEMBAHASAN}

Hasil penelitian tentang judul hubungan mobilisasi dini post Sectio Caesarea dengan penyembuhan luka operasi di RSU Avicenna Bireuen tahun 2019 dapat dilihat bahwa mayoritas umur ibu yaitu 20-35 tahun sebanyak 25 orang $(78,1 \%)$ dan minoritas umur yaitu $<20$ tahun yaitu 2 responden $(6,3 \%)$.. Usia merupakan suatu faktor proses penyembuhan luka. Kecepatan perbaikan sel berlangsung sejalan dengan pertumbuhan atau kematangan usia seseorang, namun selanjutnya proses penuaan dapat memperlambat proses penyembuhan luka 
Journal of Healthcare Technology and Medicine Vol. 5 No. 2 Oktober 2019

Universitas Ubudiyah Indonesia

e-ISSN : 2615-109X

(Hidayat, 2007). Menurut Bartini (2012), usia reproduksi sehat adalah usia yang aman bagi seseorang untuk hamil dan melahirkan yaitu usia 20-35 tahun. Sementara usia 35 tahun atau lebih merupakan kehamilan resiko tinggi.

Ditinjau dari tingkat pendidikan dapat dilihat mayoritas pendidikan responden berada pada kategori menengah yaitu 13 responden (40,6\%). Dan minoritas tingkat pendidikan berada pada kategori tingkat tinggi yaitu 9 responden $(28,1 \%)$. Tingkat pendidikan merupakan salah satu faktor yang memungkinkan terjadinya pengetahuan. Menurut Maryanti (2009), pendidikan berpengaruh kepada sikap wanita terhadap kesehatan yang munkin terjadi terhadap diri mereka.

Dilihat dari karakteristik pekerjaan mayoritas pekerjaan ibu adalah ibu yang tidak bekerja yaitu 21 responden $(65,6 \%)$, dan minoritas pekerjaan ibu adalah ibu yang bekerja yaitu sebanyak 11 responden $(34,4 \%)$. Berdasarkan hasil wawancara dari beberapa pasien ibu yang bekerja ingin lebih cepat sembuh dan kembali bekerja seperti biasanya. Sedangkan ibu yang tidak bekerja juga ingin segera sembuh agar bisa kembali beraktifitas.

Hasil distribusi mobilisasi dini didapatkan mayoritas responden melakukan mobilisasi dini dengan baik yaitu 21 responden $(65,6 \%)$ sedangkan minoritas yaitu responen yang melakukan mobilisasi dengan kategori rendah $(34,4 \%)$. Dikarenakan ibu masih mempunyai kekhawatiran jika tubuh digerakkan pada posisi tertentu pasca pembedahan akan mempengaruhi luka operasi yang masih belum sembuh yang baru saja selesai dikerjaan juga mempunyai kemauan yang rendah dengan alasan nyeri yang tidak bisa ditahan ibu saat diminta bergerak. Padahal menurut Wulandari (2010), yang menjadi dasar utama yang mempengaruhi penyembuhan luka adalah kemauan ibu untuk melakukan mobilisasi dini post Sectio Caesarea. 
Journal of Healthcare Technology and Medicine Vol. 5 No. 2 Oktober 2019

Universitas Ubudiyah Indonesia

e-ISSN : 2615-109X

Berdasarkan distribusi penyembuahan luka mayoritas penyembuhan luka berada pada kategori sembuh cepat yaitu 22 responden $(68,8 \%)$ dan minoritas penyembuhan luka pada kategori sembuh lambat yaitu 10 responden (31,2\%). Penyembuhan luka yang kurang baik atau sembuh lambat seperti luka yang sudah rapat tetapi lukanya masih basah. Hal tersebut dikarenakan banyak faktor lain yang dapat memperlambat penyembuhan luka. Menurut Eka Putra (2013) faktor-faktor yang mempengaruhi penyembuhan luka ada 2 yaitu faktor local dan faktor umum. Faktor local seperti praktek manajemen luka, infeksi dan adanya benda asing. Sedangkan menurut faktor umum yaitu usia, nutrisi, steroid, penyakit ibu dan obat-obatan.

Berdasarkan hasil tabulasi silang dapat diketahui bahwa responden yang melakukan mobilisasi dengan baik yaitu ada 21 responden (65,6\%). Penyembuhan luka cepat ada 19 responden $(59,4 \%)$ dan penyembuhan luka lambat ada 2 responden $(6,2 \%)$. Responden yang tidak melakukan mobilisasi kategori kurang ada 11 responden $(34,4 \%)$ dengan penyembuhan luka cepat ada 3 reponden $(9,4 \%)$ dan penyembuhan luka secara lambat ada 8 responden $(25 \%)$. Untuk responden yang melakukan mobilisasi dengan kategori kurang dan mengalami penyembuhan luka secara cepat itu didukung oleh faktor pendukung lain yang mempengaruhi penyembuhan luka.

Hasil uji statistik menggunakan uji Chi-square diperoleh nilai $\rho$-value 0,001 $(0,001<0,05)$, maka ha diterima dan $\mathrm{H} 0$ ditolah, hasil statistik ini menunjukkan bahwa ada hubungan yang signifikan antara Mobilisasi Dini Post Sectio caesarea dengan penyembuhan luka operasi di RSU Avicenna Bireuen tahun 2019.

Hasil penelitian ini sejalan dengan hasil penelitian yang dilakukan oleh Rimayanti Simangunsong (2018) dengan judul hubungan mobilisasi dini post sectio caesarea di RSU SMIM Pancaran kasih Manado dengan hasil penelitian bahwa ada hubungan antara mobilisasi 
Journal of Healthcare Technology and Medicine Vol. 5 No. 2 Oktober 2019

Universitas Ubudiyah Indonesia

e-ISSN : 2615-109X

dini post sectio caesarea dengan penyembuhan luka operasi dengan perolehan nilai ( $\rho$ value $=0.001$ )

Mobilisasi dini merupakan faktor yang berhubungan dengan pemulihan luka post Sectio Caesarea karena salah satu manfaat mobilisasi dini adalah melancarkan sirkulasi darah. Sirkulasi darah yang lancar dapat membantu dalam proses penyembuhan luka karena darah mengandung zat-zat yang dibutuhkan untuk penyembuhan luka seperti oksigen, obatobatan, gizi dan lain-lain.

Menurut asumsi peneliti mobilisasi dini merupakan salah satu faktor utama yang mendukung proses penyembuhan luka operasi post Sectio Caesarea. apabila mobilisasi dilakukan dengan baik maka penyembuhan luka terjadi secara cepat. Namun ada 2 responden $(6,2 \%)$ yang melakukan mobilisasi dengan baik tetapi mengalami penyembuhan luka secara lambat berdasarkan hasil observasi tampak bahwa responden kurang memperhatikan personal hygine dan nutrisinya yang disebabkan oleh berbagai faktor termasuk responden yang mengalami stres, sedangkan 3 reponden $(9,4 \%)$ yang melakukan mobilisasi dengan kategori kurang tetapi mengalami proses penyembuhan luka secara cepat itu disebabkan oleh responden yang melakukan personal hygine dengan tepat dan dengan nutrisi yang terpenuhi.

\section{KESIMPULAN}

Berdasarkan hasil penelitian dan pembahasan yang telah dijelaskan pada bab-bab sebelumnya, kesimpulan yang dapat ditarik dan penelitian ini adalah Sebagian besar responden melakukan mobilisasi dini dengan baik di RSU Avicenna Bireuen tahun 2019 yaitu sebanyak 21 responden (65,5\%), Penyembuhan luka operasi ibu mayoritas berada pada kategori cepat yaitu sebanyak 22 responden (68,8\%), dan Berdasarkan hasil uji Chi-square didapatkan nilai $\rho(0,001)<(0,05)$, sehingga ada hubungan antara mobilisasi dini post Sectio Caesarea dengan penyembuhan luka operasi. 
Journal of Healthcare Technology and Medicine Vol. 5 No. 2 Oktober 2019

Universitas Ubudiyah Indonesia

e-ISSN : 2615-109X

\section{SARAN}

Diharapkan bagi tenaga kesehatan khususnya di RSU Avicenna Bireuen untuk lebih aktif melakukan penyuluhan tentang pentingnya melakukan mobilisasi dini post Sectio Caesarea, dan mengajarkan ibu cara merawat dan menjaga kebersihan diri guna untuk mencegah infeksi.

\section{DAFTAR PUSTAKA}

A.Azis Alimul Hidayat. (2014). Metode Penelitian Kebidanan dan Teknik Analisis Data. Saleba Medika. Jakarta Selatan.

Aliahani, 2010. Mobilisasi dini pada ibu post sectio caesarea. http://honey72.wordpress.com. diakses pada tanggal 05 April 2019

Ambarwati \& Wulandari (2010). Asuhan Kebidanan Nifas. Yogyakarta : Nuha Medika

Astutik, Y.R. (2015). Asuhan Kebidanan Masa Nifas dan Menyusui, Jakarta : CV. Trans Info Media.

Ayu Ashari. (2017). Hubungan Mobilisasi dini Post Sectio Caesarea dengan penyembuhan Luka bekas operasi di Ruang Kebidaanan Rumah sakit Umum Dewi Sartika.

Bartini I. (2012). Buku pintar panduan dan tips hamil sehat. Yogyakarta : Nuha medika

Boyle, M. Pemulihan luka (Wound Healing in Midwifery). Jakarta :EGC. 2009.

Christina, S., \& Kristanti, E. E. (n.d.). Mobilisasi Dini Berhubungan Dengan Peningkatan Kesembuhan Luka pada pasien Post Operasi Sectio Caesarea, 1-8.

Chrisna Trirestuti (2018). Asuhan Kebidanan 2. Trans Info Media. Jakarta.

Dinkes aceh. (2013). profil kesehatan provinsi aceh, 2013 diambil dari www.depkes.go.ig diakses oleh Ferinawati pada tangga 05 April 2019

Forte, R \& Oxorn, H. (2010). Ilmu Kebidanan : Patologi persalinan. Yogyakarta : CV. Andi Offset

Hidayat A. (2007). Metode penelitian kebidanan teknik analisis data. Jakarta :Salemba medika

Iman. (2016). Panduan Penyusunan Karya Tulis Ilmiah Bidang Kesehatan. Cita Pustaka Media Perintis. Jakarta.

Iman. (2012). Pemanfaatan SPSS dalam penelitian Bidang Kesehatan. Citapustaka Media Perintis. 
Journal of Healthcare Technology and Medicine Vol. 5 No. 2 Oktober 2019

Universitas Ubudiyah Indonesia

e-ISSN : 2615-109X

Kemenkes RI. (2015). Kesehatan dalam rangka Sustinable Development Goals (SDGS).

Diakses oleh ferinawati tanggal 30 April 2019.

Kemenkes RI. (2013). Riset kesehatan Dasar Tahun 2013. Jakarta : Kemenkes RI.

Kuswantoro Rusca P, Dina Dewi, M.B. (2012). Pengaruh Mobilisasi Dini terhadap Proses Penyembuhan Luka dan lama Hari Rawat, (Majalah Kesehatan FKUB).

Marfuah, I. (2015). Hubungan tingkat pengetahuan dengan sikap ibu dalam mobilisasi dini pasca sectio caesarea dirumah sakit umum daerah Dr. Moewardi.

Maryanti D, Septikasari M. (2009). Buku ajar kesehatan reproduksi terapi dan praktikum dalam Ari Setiawan. Yogyakarta : Nuha Medika.

Medical record RSU Avicenna Bireuen. Jumlah Pasien sectio Caesarea Di RS Avicenna

Mirza Maulana (2013). Panduan Lengkap Kehamilan. Katahari.

M.T. Indriati (2015). Kehamilan, Persalinan, Perawatan bayi. Indoliterasi.

Niclasson. (2015). Pain Relief Following Cesarean Section Short and Long Term Perspektive, Sweden university

Nur Islah ramadhani. (2018). Hubungan Mobilisasi Dini Post Sectio Caesarea dengan Proses penyembuhan Luka operasi di ruang Nifas RSu Dewi Sartika Kota Kendari

Notoatmojo. (2010). Metode penelitian kesehatan. Jakarta : Rineka Cipta

Puspitasari, 2011. Faktor-faktor yang mempengaruhi penyembuhan luka post operasi sectio caesarea di RS PKU Muhammadiyah Gombong. Http//www//skripsi_stikes.com. diakses pada tanggal 05 April 2019.

Riset kesehatan dasar (RISKESDAS). (2013). http://hasilriskesdas2013.pdf diakses pada tanggal 10 April 2019

Rimayanti Simangunsong (2018). Hubungan mobilisasi dini dengan proses penyembuhan luka post sectio caesarea di RSU GMIM pancaran kasih Manado. diambil dari e-journal Keperawatan (e-kep) Volume 6 nomor 1, Februari 2018 diakses pada tanggal 05 April 2019.

Suriadi, 2007. Operasi sectio caesarea (online) available : http://www.indoskripsi.co.id. diakses pada tanggal 05 april 2019

Yuli Styowati, S. (2013). karakteristik yang memperngaruhi mobilisasi dini ibu post Sectio Caesarea. jurnal kebidanan, II(Embrio). 